\title{
Peningkatan Kemampuan Membaca dengan Pemanfaatan Media Kartu Kata pada Anak Didik Kelompok B2 TKN Pembina Kecamatan Kepanjenkidul Kota Blitar
}

\author{
Eko Agus Ningsih \\ TKN Pembina Kecamatan Kepanjenkidul Kota Blitar, Indonesia \\ Email: ekoningsih@gmail.com
}

\begin{tabular}{l}
\hline Tersedia Online di \\
\hline $\begin{array}{l}\text { http://www.jurnal.unublitar.ac.id/in } \\
\text { dex.php/briliant }\end{array}$ \\
\hline Sejarah Artikel \\
\hline Diterima pada 9 November 2019 \\
Disetujui pada 27 November 2019 \\
Dipublikasikan pada 30 November \\
2019 Hal. 494-501 \\
\hline
\end{tabular}

\section{Kata Kunci:}

Kemampuan Membaca, Media

Kartu Kata, Taman Kanak-Kanak

\section{DOI:}

http://dx.doi.org/10.28926/briliant.v $3 \mathrm{i} 4.407$

\begin{abstract}
Abstrak: Penelitian ini bertujuan untuk mendeskripsikan pelaksanaan dan pemanfaatan media kartu kata dalam peningkatan kemampuan membaca anak didik kelompok B2 Semester 1 Tahun Pelajaran 2019/2020 TKN Pembina Kecamatan Kepanjenkidul Kota Blitar. Hasil dari penelitian ini adalah kartu kata dapat meningkatkan kemampuan membaca anak. Hal tersebut dapat dilihat dari hasil ketuntasan belajar klasikal prasiklus mencapai 53,9\%, siklus I sebesar 64,5\%, dan siklus II sebesar 77,23\%. Selain itu, proses pelaksanaan pembelajar menunjukkkan bahwa siklus I mencapai hasil $68 \%$ dan siklus II mencapai hasil 90,7\%. Dari data tersebut, dapat disimpulkan bahwa pemanfaatan media kartu kata dapat meningkatkan kemampuan membaca anak dan kualitas proses pembelajaran membaca.
\end{abstract}

\section{PENDAHULUAN}

Pendidikan usia dini/ TK bertujuan untuk memfasilitasi pertumbuhan dan perkembangan seluruh aspek kepribadian anak. Oleh karena itu, TK perlu menyediakan berbagai kegiatan yang dapat mengembangkan berbagai aspek perkembangan yang meliputi kognitif, bahasa, sosial, emosional, fisik, dan motorik (Anderson, dalam Masitoh, 2008:1.8). Penyelenggaraan kegiatan di TK harus tetap memerhatikan pertumbuhan dan perkembangan anak didik, sehingga anak didik merasa nyaman dan aman dalam mencari pengalaman baru untuk perkembangan dirinya.

Bahasa merupakan sebuah sarana yang dapat menunjang individu untuk hidup dengan orang lain. Dengan adanya bahasa, seseorang dapat menyatakan pikiran, perasaan, dan keinginanya. Orang yang diajak berkomunikasi akan paham dengan maksud dan tujuan pesan yang disampaikan oleh orang yang mengajak komunikasi. Dengan demikian, bahasa merupakan alat komunikasi antar individu dengan individu lainya dalam menyampaikan suatu pesan.

Pada penyelenggaraan pendidikan di TK, bahasa merupakan salah satu aspek yang perlu dikembangkan, karena bahasa merupakan alat komunikasi utama bagi seorang anak didik untuk mengungkapkan berbagai keinginan maupun 
kebutuhannya. Apabila kemampuan bahasa baik, maka anak didik dengan mudah memahami pesan yang disampaikan oleh guru dalam suatu kegiatan pembelajaran, sehingga apa yang menjadi tujuan pembelajaran dapat berhasil maksimal.

Anak memperoleh wawasan yang lebih luas dalam segala hal dan membuat belajar lebih mudah jika mampu membaca. Anak juga akan memiliki rasa kebahasaan yang tinggi. Kegiatan membaca mencakup beberapa kegiatan, seperti mengenali huruf dan kata, menghubungkan dengan bunyi, memahami, serta menarik kesimpulan mengenai bacaan. Membaca merupakan salah satu bentuk dari bahasa, oleh karena itu pengembangan kemampuan bahasa perlu dilakukan sejak dini.

Berdasarkan observasi yang telah dilakukan pada anak didik kelompok B2 TKN Pembina Kecamatan Kepanjenkidul Kota Blitar, terdapat lebih dari separuh dari jumlah keseluruhan anak belum dapat membaca kata sederhana yang diajarkan oleh guru. Anak didik tidak bisa menjawab ketika guru mengajukan pertanyaan tetang kata-kata yang ditunjukkan oleh guru. Berdasarkan observasi yang telah dilaksanakan, kesulitan anak tersebut disebabkan oleh terbatasnya media pembelajaran.

Derek Rowntrie dalam Sumantri (1999:179) menyebutkan terdapat beberapa fungsi media pembelajaran, antara lain: (a) membangkitkan motivasi belajar siswa, (b) mengulang apa yang telah dipelajari, (c) menyediakan rangsangan untuk belajar, (4) mengaktifkan respon siswa, dan (d) memberikan latihan yang serasi. Selain itu, pemakaian media pembelajaran dapat dikaitkan dengan salah satu tujuan berikut ini, yaitu: (a) pembentukan konsep, (b) pembentukan pemahaman, (c) latihan dan penguatan, (d) melayani perbedaan individual, (e) pengamatan dan penemuan sendiri, (f) pemecahan masalah, (g) merangsang untuk berfikir, (h) merangsang untuk berdiskusi, serta (i) merangsang untuk berpartisipasi aktif dalam pembelajaran.

Sementara Levie \& Lentz dalam Arsyad (2004: 16) mengemukakan empat fugsi media pembelajaran, khususnya media visuial, yaitu: (a) fungsi atensi, (b) fungsi afektif, (c) fungsi kognitif, dan (d) fungsi kompensatoris. Fungsi atensi adalah upaya untuk menarik dan mengarahkan perhatian siswa untuk berkonsentrasi kepada isi pelajaran. Fungsi afektif dapat terlihat dari tingkat kenikmatan siswa ketika belajar. Fungsi kognitif terlihat dari temuan-temuan penelitian yang mengungkap bahwa lambang visual atau gambar memperlancar pencapaian tujuan. Fungsi kompensatoris berfungsi untuk mengakomodasikan siswa yang lemah dan lambat menerima isi pelajaran.

Pada penelitian ini, peneliti memanfaatkan media kartu kata dengan harapan kemampuan anak didik dalam membaca awal dapat meningkat. Kartu kata adalah salah satu media pembelajaran yang berupa potongan-potongan kartu berbentuk persegi panjang yang bertuliskan satu kata yang berfungsi sebagai alat bantu anak dalam belajar membaca.

Penelitian ini bertujuan untuk mendeskripsikan pelaksanaan dan pemanfaatan media kartu kata dalam peningkatan kemampuan membaca anak didik kelompok B2 Semester 1 Tahun Pelajaran 2019/2020 TKN Pembina Kecamatan Kepanjenkidul Kota Blitar. Penelitian ini diharapkan dapat digunakan sebagai acuan dalam melaksanakan kegiatan pembelajaran membaca awal pada anak, memotivasi anak didik untuk belajar membaca tanpa adanya paksaan, dapat 
digunakan sebagai bahan masukan dalam peran serta meningkatkan mutu pendidikan di sekolah, serta orang tua dapat membantu anak dalam belajar membaca dengan memanfaatkan media kartu kata secara mandiri.

\section{METODE}

Penelitian ini merupakan jenis Penelitian Tindakan Kelas (PTK). Penelitian Tindakan Kelas adalah suatu proses investigasi terkendali yang bertujuan untuk menemukan dan memecahkan masalah pembelajaran yang ada di kelas. Proses pemecahan masalah tersebut dilakukan secara bersiklus untuk meningkatkan kualitas pembelajaran di kelas (Akbar, 2009: 26).

Model penelitian tindakan yang digunakan adalah model yang dikembangkan oleh Kemis \& MC. Taggart, dalam Akbar (2009:28). Adapun bagan dari PTK dapat dilihat dalam Gambar 1.

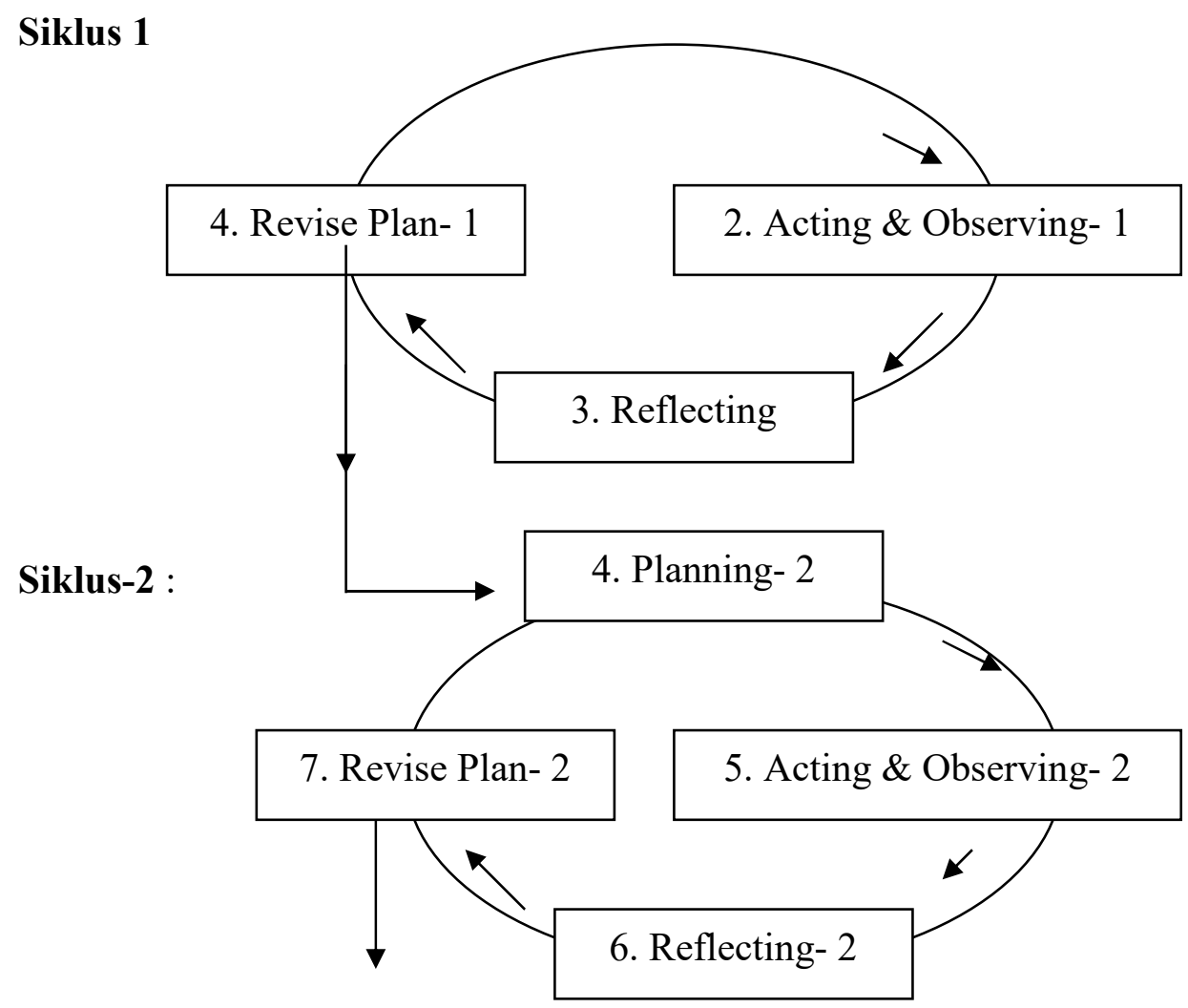

Gambar 1. Bagan penelitian tindakan kelas

Berdasarkan Gambar 1, dapat dilihat bahwa terdapat dua siklus pada penelitian tindakan kelas, di mana setiap siklus terdiri dari planning (perencanaan), acting \& observasing (tindakan \& pengamatan), reflecting (refleksi), revise plan (revisi rencana) untuk siklus berikutnya.

Salah satu karakteristik dalam penelitian tindakan kelas yaitu terdapat kegiatan yang dilakukan secara bersiklus. Setiap siklus terdiri dari beberapa tahap yaitu perencanaan, tindakan, observasi, dan refleksi. Hasil refleksi digunakan sebagai dasar untuk perbaikan, proses, dan hasil pembelajaran pada siklus berikutnya. Pada penelitian ini adalah model PTK guru sebagai peneliti, dengan 
berkolaborasi dengan teman sejawat yang mengajar di kelompok B1 TKN Pembina Kecamatan Kepanjenkidul. Penelitian ini akan diakhiri jika sudah terjadi peningkatan kualitas proses dan hasil pembelajaran. Kegiatan yang dilakukan pada siklus I adalah berdasarkan hasil pengamatan pada kegiatan prasiklus.

Penelitian dilaksanakan di kelompok B2 TKN Pembina Kecamatan Kepanjenkidul Kota Blitar pada semester satu tahun pelajaran 2019/2020. Subyek dalam penelitian ini adalah anak didik kelompok B2 TKN Pembina Kecamatan Kepanjenkidul Kota Blitar dengan jumlah 15 anak, yang terdiri dari tujuh perempuan dan 8 laki-laki.

Analisis data dilakukan untuk mengetahui keberhasilan kegiatan pembelajaran. Penelitian ini menggunakan teknik analisis deskriptif kualitatif yang menggambarkan kenyataan sesuai data yang diperoleh untuk mengtehaui peningkatan minat belajar membaca, kegiatan pembelajaran, serta aktivitas anak didik selama proses belajar.

\section{HASIL}

Kemampuan membaca anak pada siklus satu belum sesuai dengan yang diharapkan. Dalam kegiatan ini anak belum semua mau memerhatikan guru sehingga waktu diberi tugas membaca anak tidak bisa membaca kata pada kartu kata yang diambilnya sesuai dengan perintah guru. Data kemampuan membaca pada siklus satu dapat dilihat pada Tabel 1. Adapun Tabel 2 menerangkan rincian kemampuan membaca pada siklus dua.

Tabel 1. Nilai kemampuan membaca pada siklus satu

\begin{tabular}{|c|c|c|c|c|c|c|c|}
\hline \multirow{2}{*}{ No } & \multirow{2}{*}{$\begin{array}{l}\text { Nama } \\
\text { Anak } \\
\text { Didik }\end{array}$} & \multicolumn{3}{|c|}{ Aspek yang diamati } & \multirow{2}{*}{$\begin{array}{c}\text { Jml nilai } \\
\text { kemampuan } \\
\text { membaca }\end{array}$} & \multirow{2}{*}{$\begin{array}{c}\text { Nilai } \\
\text { kemampuan } \\
\text { membaca } \\
\text { dalam \% }\end{array}$} & \multirow{2}{*}{ Ket } \\
\hline & & Lafal & Intonasi & Kelancaran & & & \\
\hline 1 & Bagus & 2 & 2 & 3 & 7 & 58,3 & BT \\
\hline 2 & Hendik & 3 & 3 & 4 & 10 & 83,3 & $\mathrm{~T}$ \\
\hline 3 & Fikri & 3 & 3 & 3 & 9 & 75 & $\mathrm{~T}$ \\
\hline 4 & Raka & 2 & 2 & 2 & 6 & 50 & BT \\
\hline 5 & Lutfi & 2 & 2 & 1 & 5 & 41,7 & BT \\
\hline 6 & Lucky & 3 & 2 & 2 & 7 & 58,3 & BT \\
\hline 7 & Leksi & 3 & 2 & 3 & 8 & 66,7 & BT \\
\hline 8 & Putra & 3 & 2 & 2 & 7 & 58,3 & BT \\
\hline 9 & Cidy & 3 & 3 & 2 & 8 & 66,7 & BT \\
\hline 10 & Elsa & 3 & 3 & 4 & 10 & 83,3 & $\mathrm{~T}$ \\
\hline 11 & Naura & 2 & 2 & 2 & 6 & 50 & BT \\
\hline 12 & Wina & 2 & 2 & 2 & 6 & 50 & BT \\
\hline 13 & Winda & 3 & 3 & 3 & 9 & 75 & $\mathrm{~T}$ \\
\hline 14 & Windi & 3 & 3 & 3 & 9 & 75 & $\mathrm{~T}$ \\
\hline 15 & Verda & 3 & 3 & 3 & 9 & 75 & $\mathrm{~T}$ \\
\hline \multicolumn{2}{|c|}{$\begin{array}{l}\text { Skor } \\
\text { keberhasilan }\end{array}$} & $66,7 \%$ & $61,7 \%$ & $65 \%$ & & & \\
\hline \multicolumn{2}{|c|}{$\begin{array}{l}\text { Ketuntasan } \\
\text { klasikal }\end{array}$} & & $64,5 \%$ & & & & \\
\hline
\end{tabular}


Tabel 2. Nilai kemampuan membaca pada siklus dua

\begin{tabular}{|c|c|c|c|c|c|c|c|}
\hline \multirow[b]{2}{*}{ No } & \multirow{2}{*}{$\begin{array}{l}\text { Nama } \\
\text { Anak } \\
\text { Didik }\end{array}$} & \multicolumn{3}{|c|}{ Aspek yang diamati } & \multirow{2}{*}{$\begin{array}{c}\text { Jml nilai } \\
\text { kemampuan } \\
\text { membaca }\end{array}$} & \multirow{2}{*}{$\begin{array}{c}\text { Nilai } \\
\text { kemampuan } \\
\text { membaca } \\
\text { dalam \% }\end{array}$} & \multirow[b]{2}{*}{ Ket } \\
\hline & & Lafal & Intonasi & Kelancaran & & & \\
\hline 1 & Bagus & 3 & 3 & 3 & 9 & 75 & $\mathrm{~T}$ \\
\hline 2 & Hendik & 4 & 3 & 4 & 11 & 91,7 & $\mathrm{~T}$ \\
\hline 3 & Fikri & 3 & 3 & 4 & 10 & 83,3 & $\mathrm{~T}$ \\
\hline 4 & Raka & 3 & 3 & 3 & 9 & 75 & $\mathrm{~T}$ \\
\hline 5 & Lutfi & 3 & 3 & 2 & 8 & 66,7 & BT \\
\hline 6 & Lucky & 3 & 3 & 3 & 9 & 75 & $\mathrm{~T}$ \\
\hline 7 & Leksi & 3 & 3 & 3 & 9 & 75 & $\mathrm{~T}$ \\
\hline 8 & Putra & 3 & 3 & 2 & 8 & 66,7 & BT \\
\hline 9 & Cidy & 3 & 3 & 3 & 9 & 75 & $\mathrm{~T}$ \\
\hline 10 & Elsa & 3 & 3 & 4 & 10 & 83,3 & $\mathrm{~T}$ \\
\hline 11 & Naura & 3 & 3 & 3 & 9 & 75 & $\mathrm{~T}$ \\
\hline 12 & Wina & 3 & 3 & 2 & 8 & 66,7 & BT \\
\hline 13 & Winda & 3 & 3 & 4 & 10 & 83,3 & $\mathrm{~T}$ \\
\hline 14 & Windi & 3 & 3 & 4 & 10 & 83,3 & $\mathrm{~T}$ \\
\hline 15 & Verda & 3 & 3 & 4 & 10 & 83,3 & $\mathrm{~T}$ \\
\hline \multicolumn{2}{|c|}{$\begin{array}{l}\text { Skor } \\
\text { keberhasilan }\end{array}$} & $76,7 \%$ & $75 \%$ & $80 \%$ & & & \\
\hline \multicolumn{2}{|c|}{$\begin{array}{l}\text { Ketuntasan } \\
\text { klasikal }\end{array}$} & & $77,23 \%$ & & & & \\
\hline
\end{tabular}

\section{PEMBAHASAN}

Media pembelajaran mempunyai arti penting dalam kegiatan pembelajaran. Selain membuat anak didik lebih tertarik terhadap pembelajaran, mereka juga dapat dengan mudah menerima materi yang disampaikan oleh guru, mengonkretkan konsep-konsep yang abstrak, lebih termotivasi belajar dengan adanya media pembelajaran, serta kualitas hasil belajar anak didik lebih meningkat. Hal tersebut sesuai dengan salah satu menfaat media pembelajaran yang dikemukakan oleh Kemp dan Dayton dalam Rahardi (2004:13), bahwa salah satu manfaat media pembelajaran adalah untuk meningkatkan kualitas hasil belajar siswa. Sementara Zaman, dkk (2008: 4.10) menyatakan bahwa manfaat dari media pembelajaran di Taman kanak-kanak salah satunya adalah mengkonkretkan konsep-konsep yang abstrak.

Kondisi awal pelaksanaan pembelajaran membaca bagi anak didik kelompok B2 TKN Pembina Kecamatan Kepanjenkidul Kota Blitar menunjukkkan bahwa pelaksanaan pembelajaran belum berhasil dengan baik. Kemudian, peneliti menggunakan media kartu kata untuk membantu anak dalam belajar membaca. Kartu kata merupakan suatu kartu yang berisi potongan kata. Selain itu, pembuatan media ini juga sangat mudah (Dhieni, dkk, 2008: 9.29).

Dalam proses pembelajaran, anak diajak untuk melakukan permainan berburu kartu kata. Melalui kegiatan ini, anak dapat mengenal kata yang mempunyai suku kata awal sama, mengelompokkan kata-kata sesuai dengan 
jenisnya, dan menirukan urutan kata dari kata-kata yang telah dipelajari. Hal ini sesuai dengan indikator bidang pengembangan kemampuan bahasa di Taman Kanak-kanak. Melalui permainan ini, anak didik merasa senang dan merasa tidak dipaksa dalam belajar membaca, serta termotivasi untuk belajar membaca. Keadaan tersebut sesuai dengan salah satu prinsip pembelajaran di Taman kanakkanak, yaitu bermain sambil belajar dan belajar seraya bermain (Depdiknas, 2006: 5). Dalam hal ini, guru berperan sebagi fasilitator sekaligus pembimbing untuk anak dalam mengembangkan kemampuan yang dimilikinya.

Berdasarkan hasil penilaian proses pelaksanaan pembelajaran pada siklus I, diperoleh nilai proses sebesar $68 \%$. Sedangkan pada siklus II diperoleh nilai proses pelaksanaan pembelajaran sebesar $90,7 \%$. Hal ini terjadi peningkatan skor pada proses pelaksanaan pembelajaran sebesar 22,7\%. Berdasarkan analisis data yang dilakukan maka dapat disimpulkan bahwa terjadi peningkatan proses pelaksanaan pembelajaran dengan memanfaatkan media kartu kata.

Keberhasilan suatu tindakan dapat diketahui dengan cara pengamatan (observasi). Melalui kegiatan observasi, peneliti dapat memperoleh sebuah data keberhasilan penelitian. Berdasarkan kriteria ketuntasan minimal di TKN Pembina Kecamatan Kepanjenkidul, anak dikatakan tuntas belajar jika minimal telah mencapai nilai ketuntasan belajar sebesar $70 \%$ secara individual maupun klasikal.

Berdasarkan hasil belajar siklus I, terdapat enam anak dari 15 anak dikategorikan tuntas belajar dan 9 anak dari 15 anak dikategorikan belum tuntas belajar. Pada siklus I ketuntasan belajar secara klasikal masih tercapai $64,5 \%$ dari ketuntasan belajar minimal yaitu $70 \%$.

Pada siklus II, perolehan hasil belajar mengalami peningkatan. Peningkatan ini merupakan hasil perbaikan dari hambatan atau kendala yang muncul pada siklus I. Dari hasil siklus II, terdapat 12 anak dari 15 anak dikategorikan tuntas belajar dan tiga anak dikategorikan belum tuntas belajar. Sedangkan ketuntasan belajar secara klasikal pada siklus ini sebesar 77,23\%. Dengan demikian, terdapat peningkatan ketuntasan belajar baik secara individual maupun klasikal antara siklus I dan siklus II. Pada siklus I, ketercapaian ketuntasan belajar secara klasikal mencapai $64,5 \%$, sedangkan pada siklus II ketercapaian ketuntasan belajar secara klasikal mencapai 77,23\%, sehingga terjadi peningkatan ketuntasan belajar klasikal sebesar $12,73 \%$.

Berdasarkan uraian di atas, dapat disimpulkan bahwa pembelajaran dengan pemanfaatan media kartu kata telah membantu anak memperoleh hasil yang memuaskan yaitu mencapai standar ketuntasan minimal, dengan demikian pemanfaatan media kartu kata dapat digunakan untuk meningkatkan kemampuan membaca pada anak didik kelompok B2 Semester 1 Tahun Pelajaran 2019/ 2020 TKN Pembina Kecamatan Kepanjenkidul Kota Blitar.

Pada penelitian ini, anak didik berada dalam tahap pengenalan bacaan karena anak didik mulai tertarik pada bacaan, mengingat kembali cetakan pada konteknya, mengenal tanda-tanda pada lingkungan serta membaca berbagai tanda. Hal tersebut sesuai dengan yang dikemukakan Depdiknas (2007: 5), bahwa tahapan membaca pada anak berlangsung dalam beberapa tahapan dan salah satunya tahap pengenalan bacaan. Pada tahap ini, anak berusaha untuk mengingat dan membaca berbagai tanda seperti kotak susu, pasta gigi, atau papan iklan. 


\section{KESIMPULAN}

Berdasarkan hasil penelitian tindakan kelas yang telah dilaksanakan, maka dapat disimpulkan bahwa pelaksanan proses pembelajar membaca pada anak didik TK dengan memanfaatkan media kartu dapat berhasil dengan baik jika didukung dengan pengelolaan kelas yang baik dan kegiatan pembelajaran sesuai dengan prinsip pembelajaran di Taman Kanak-kanak. Kegiatan ini dilakukan agar anak merasa senang dan merasa tidak dipaksa dalam belajar membaca. Hal ini dapat dilihat dari hasil penilaian aktivitas anak menunjukkan bahwa pada siklus 1 anak yang mencapai ketuntasan belajar sebanyak 6 anak didik dan meningkat menjadi 11 anak didik pada siklus 2. Peneilaian tersebut meliputi konsentrasi, keaktifan dan rasa senang anak didik dalam mengikuti kegiatan pembelajaran. Pada penelitian ini menunujukkan bahwa ada peningkatan kualitas pembelajaran yaitu pada siklus 1 ke siklus 2 meningkat dari $68 \%$ menjadi $90,7 \%$, hal ini terjadi peningkatan sebesar $22,7 \%$.

Kemampuan anak dalam belajar membaca dengan memanfaatkan media kartu kata juga meningkat. Hal ini dapat dilihat dari persentase perolehan nilai ketuntasan belajar yaitu pada siklus I mencapai $64,4 \%$ dan siklus II menjadi $77,22 \%$, dengan demikian peningkatan kemampuan anak belajar membaca sebesar $12,82 \%$.

\section{SARAN}

Berdasarkan uraian dan simpulan tentang hasil penelitian dengan pemanfaatan media kartu kata, maka diajukan beberapa saran sebagai berikut: bagi guru dalam melaksanakan kegiatan pembelajaran membaca sebaiknya menggunakan media kartu kata karena sesuai dengan tahapan membaca pada anak yaitu tahap pengenalan bacaan; dalam belajar membaca dengan memanfaatkan media kartu kata sebaiknya anak didik diajak belajar melalui permainan sehingga anak didik merasa senang tanpa adanya paksaan untuk belajar membaca; agar proses pembelajaran membaca dengan memanfaatkan media kartu kata dapat berhasil dengan baik sebaiknya guru mengelola kelas dengan baik sehingga anak merasa nyaman dan lebih berkonsentrasi dalam menerima pembelajaran; bagi penyelenggara pendidikan Taman kanak-kanak sebaiknya dalam menyediakan kartu kata tidak terbatas sejumlah anak sehingga anak tidak akan berebut dalam menggunakan media kartu kata; bagi peneliti selanjutnya dalam menggunakan media kartu kata dalam kegiatan pembelajaran membaca sebaiknya memilih strategi yang tepat agar anak tidak merasa bosan..

\section{DAFTAR RUJUKAN}

Akbar, Sa'dun. 2009. Penelitian Tindakan Kelas Filosofis, Metodologi \& Implementasi. Yogyakarta: Cipta Media.

Arsyad, Azhar. 2004. Media Pembelajaran. Jakarta: Raja Grafindo Persada.

Depdiknas, 2007. Pedoman Pembelajaran Bidang pengembangan Berbahasa di Taman Kanak-kanak. Jakarta: Depdiknas.

Depdiknas. 2007. Pedoman Pembelajaran Persiapan Membaca dan Menulis Melalui Permainan di Taman Kanak-kanak. Jakarta: Depdiknas.

Dhieni, Nurbiana, dkk. 2008. Metode pengembangan Bahasa. Jakarta: Universitas Terbuka. 
Masitoh, dkk. 2008. Strategi Pembelajaran TK. Jakarta: Universitas Terbuka. Rahardi, Arsito. 2004. Media Pembelajaran. Jakarta: Depdiknas.

Sumantri, Mulyani \& Johar Permana. 1999. Strategi Belajar Mengajar. Jakarta: Depdikbud Dirjen Dikti.

Zaman, Badru, dkk. 2008. Media dan Sumber Belajar TK. Jakarta: Universitas Terbuka. 